Information for Authors

\section{Avis aux auteurs}

The purpose of the Canadian Journal of Philosophy is the publication in Canada of philosophical work of high quality, in English or French, and in any field of philosophy. All submissions are given blind editorial review; those of departmental colleagues are externally refereed.

Manuscripts should be sent in triplicate to: Executive Secretary, Canadian Journal of Philosophy, Department of Philosophy, University of Lethbridge, Lethbridge, Alberta, Canada T1K 3M4. It is preferred that manuscripts be typed double-spaced, including quotes and footnotes. In general, the Canadian Journal of Philosophy follows The University of Chicago Manual of Style. Footnotes should be numbered consecutively and assembled on separate pages at the end of the manuscript. Manuscripts will not be returned unless return postage is prepaid by cheque, money-order, reply coupons, or Canadian stamps.

Authors will receive, without charge, 25 copies of their articles. Additional offprints may be ordered when the proofs are returned to the publisher.

The articles in C.J.P. are indexed in The Philosophers' Index, Bowling Green, Ohio, U.S.A., in the Reportoire bibliographique de la philosophie, Louvain, Belgium, and in the Canadian Periodical Index.

All enquiries of an editorial nature should be directed to the Executive Secretary at the above address.

The Canadian Journal of Philosophy a pour objet la publication canadienne, en langues anglaise ou française, d'études philosophiques de haut niveau, quel que soit le domaine philosophique auxquelles elles appartiennent. Les communications sont évaluées dans l'anonymat de leurs auteurs; celles que soumettent les collègues départementaux sont référées à un comité de lecture extérieur.

Les manuscrits, en triple exemplaire, doivent être adressés à La Secrétaire de Rédaction. Canadian Journal of Philosophy, University of Lethbridge, Lethbridge, Alberta, Canada T1K 3M4. Soumettre de préférence des manuscrits (citations et notes comprises) dactylographiés à double interligne, en prenant pour guide, dans la mesure du possible, The University of Chicago Manual of Style. Les notes doivent suivre la numérotation continue et figurer sur des feuilles indépendantes en annexe au manuscrit. Les textes non insérés ne sont rendus qu'en cas de prépaiement des frais de poste par chèque, mandat, coupons-réponse ou timbres canadiens.

Les auteurs recoivent gratuitement 25 tirés-à part de leur article. Ils sont priés, s'ils désirent en obtenir un plus grand nombre à titre onéreux, en informer l'imprimeur lors du renvoi des épreuves.

Les articles du C.J.P. sont catalogués dans The Philosopher's Index, Bowling Green, Ohio, E.-U., dans le Répertoire bibliographique de la philosophie, Louvain, Belgique, et dans l'Index de Périodiques Canadiens. 
Subscription Information
The Canadian Journal of Philosophy is published by the University of Calgary Press. Its sponsor is the Canadian Association for Publishing in Philosophy.

The Canadian Journal of Philosophy is published quarterly, in March, June, September and December. In addition to these regular issues, the C.J.P. publishes annually a supplementary volume of original papers on a selected theme of contemporary philosophical interest. This supplementary volume is free to individual and student subscribers to the journal in that year. Supplementary volumes may also be purchased separately.

Correspondence regarding subscriptions, renewals, single issues and supplementary volume orders should be addressed to Canadian Journal of Philosophy c/o The University of Calgary Press, University of Calgary, Calgary, Alberta, Canada T2N 1N4.

A subscription for the 1990 volume of four issues is:

$\begin{array}{lrr} & \text { Canada } & \text { Outside Canada } \\ \text { Institutions } & \text { Cdn. } \$ 35.00 & \text { US } \$ 36.00 \\ \text { Individuals } & 20.00 & 20.00 \\ \text { Students } & 13.00 & 13.00 \\ \text { Single issues } & 9.00 & 9.00\end{array}$

A joint subscription to Canadian Journal of Philosophy and the Australasian Journal of Philosophy is available to individuals at $\$ 34$ and to students at $\$ 20$. Residents of Canada, Australia and New Zealand may remit in their respective currencies; for all others, prices are in US dollars.
The University of Calgary Press, The University of Calgary, CALGARY, Alberta, Canada T2N $1 \mathrm{~N} 4$

\begin{abstract}
1990 Subscription $\square \quad$ Individual $\square$ 1990 Joint Subscription $\square \quad$ Student
\end{abstract} Back Issue $\square$ No.

Please send me information on C.J.P. Supplementary Volumes

Name

Address

City

Country Postal Code

Visa $\square \quad$ Mastercard $\square \quad$ No.

Expiry Date Signature

Cheques should be made payable to The University of Calgary Press. 
Abonnements The Canadian Journal of Philosophy est publié par The University of Calgary Press sous l'égide de l'Association Canadienne de Publications en Philosophie.

The Canadian Journal of Philosophy est une publication trimestrielle paraissant en mars, juin, septembre et octobre. Outre ses quatre fascicules réguliers, il publie, annuellement, un supplément thématique d'articles inédits consacrés à des sujets d'actualité philosophique. Le supplément est offert gratuitement à tout abonné - particulier ou étudiant - de l'année courante. Les suppléments sont également disponibles à titre onéreux.

Toute correspondance concernant l'administration (abonnements, renouvellements, commandes de numéros et de suppléments) doit être adressée à The Canadian Journal of Philosophy, c/o The University of Calgary Press, The University of Calgary, Calgary, Alberta, Canada T2N 1N4. Tarifs d'abonnement au volume 1990 (4 fascicules):

$\begin{array}{lrr} & \text { Canada } & \text { Hors-Canada } \\ \text { Institutions } & \text { Cdn. } \$ 35.00 & \text { US } \$ 36.00 \\ \text { Individus } & 20.00 & 20.00 \\ \text { Etudiants } & 13.00 & 13.00 \\ \text { Numéro simple } & 9.00 & 9.00\end{array}$

Tout individu ou étudiant peut souscrire, à raison de $\$ 34$ et $\$ 20$ respectivement, un double abonnement au Canadian Journal of Philosophy et à l'Australasian Journal of Philosophy. Règlement acceptable en monnaie nationale pour les résidents du Canada, de l'Australie et de la Nouvelle-Zélande; pour tous les autres, règlement en dollars US.

\section{Canadian Joumal of Philosophy}

The University of Calgary Press, The University of Calgary, CALGARY, Alberta, Canada T2N 1N4
Abonnement $1990 \square \quad$ Individu $\square$ Double Abonnement $1990 \square \quad$ Etudiant $\square$ Numéros disponsibles $\square \quad$ No.

Veuillez me faire parvenir tous les renseignements concernant les suppléments du C.J.P.

Nom

Adresse

Ville

Pays Code Postal

Visa $\square \quad$ Mastercard $\square \quad$ No.

Date d'expiration Signature 


\author{
Other \\ Business \\ Information
}

All business correspondence, except that regarding subscriptions, renewals and single orders, should be addressed to The Managing Editor, C.J.P., Department of Philosophy, University of Alberta, Edmonton, Alberta, Canada T6G 2E5. This includes enquiries concerning advertising and promotion, exchanges, and reprinting. The copyright for all materials appearing in the regular issues and in the supplements of this journal is held by the Canadian Journal of Philosophy, and consent for any reproduction or reprinting must be obtained from the Managing Editor, with the following exception.

Permission to reproduce parts of individual numbers of Canadian Journal of Philosophy by photocopy, xerox, offset, etc., for scholarly purposes (but not for republishing by printing nor for sale to the public) is automatically granted without prior permission being secured at the following rates:

0-5 copies, no charge; 6-20 copies, 4 cents for each copy of each page of C.J.P.; additional copies, 2 cents for each copy of each page of C.J.P.

Remuneration is to be paid to the Canadian Journal of Philosophy and addressed to the Managing Editor, stating title and author of the article and number of copies. Proceeds above $\$ 10.00$ from any one article will be shared equally with the author. This announcement applies retroactively to volume I, number 1 .

\section{Services administratifs - détails supplémen- taires}

\section{Reproduction affranchie d'agrément préalable}

Toute correspondance administrative, à l'exception de celle qui concerne les abonnements, renouvellements et commandes de numéros et de suppléments, doit être adressée aux Directeur de la Publication, C.J.P., Department of Philosophy, University of Alberta, Edmonton, Alberta, Canada T6G 2E5. Ecrire à l'adresse ci-dessus pour tous renseignements relatifs à la publicité et à la promotion, ainsi qu'aux échanges et aux réimpressions. Le copyright des articles afférents aux fascicules et suppléments est propriété du Canadian Journal of Philosophy. Leur reproduction ou réimpression en tout ou partie ne peut être faite sans l'agrément préalable de le Directeur de la Publication, sauf dans le cas suivant.

Est affranchie d'agrément préalable la reproduction partielle des numéros du Canadian Journal of Philosophy par procédé technique de photocopie, xerox, offset, etc., lorsqu'elle vise exclusivement à des fins ou à des recherches académiques. Est interdite toute réimpression ayant pour objet la vente au public. Conditions tarifaires de reproduction:

0-5 copies, accordé à titre gracieux; $6-20$ copies, 4 cents par page du C.J.P.; copies supplémentaires, 2 cents par page du C.J.P.

Effectuer tout règlement à l'ordre du Canadian Journal of Philosophy et l'adresser aux Directeur de la Publication, C.J.P. Avoir soin d'indiquer le nom de l'auteur et le titre de l'article à reproduire d'une part, et le nombre de copies requises, de l'autre. Les apports provenant d'un article sont partagés à égalité avec son auteur pour la part numéraire dépassant $\$ 10.00$ (règlement rétroactif au volume I, No. 1). 


\section{$§$ C CANADIAN JOURNAL OF PHILOSOPHY \\ SUPPLEMENTARY VOLUME 14, 1988 PHILOSOPHY AND BIOLOGY}

EDITORS:

Bernard Linsky and Mohan Matthen

Bernard Linsky and Mohan Matthen

Michael Ruse

Elliott Sober

W. Ford Doolittle

R. J. Hankinson

Edwin Levy

Alexander Rosenberg

John Collier

Paul Thompson

Thomas G. Wegmann
Introduction

Evolutionary Ethics: Healthy Prospect or Last Infirmity? What is Evolutionary Altruism? Heirarchical Approaches to Genome Evolution Galen Explains the Elephant Networks and Teleology

Is the Theory of Natural Selection a Statistical Theory?

Supervenience and Reduction in Biological Heirarchies Conceptual and Logical Aspects of the 'New' Evolutionary Epistemology

Technology: The Driving Engine of Current Biological Advance

This Supplementary Volume is free to individual and student subscribes to CJP Volume 18, 1988

\section{PRICE:}

CDN $\$ 14$ in Canada

US $\$ 12$ outside Canada

Please add $\$ 1.50$ for postage

and handling and $50 \&$ for each

additional copy.

\section{ORDER FROM:}

THE UNIVERSITY OF CALGARY PRESS

THE UNIVERSITY OF CALGARY

2500 UNIVERSITY DRIVE N.W.

CALGARY, ALBERTA, CANADA T2N $1 \mathrm{~N} 4$

\section{Ð̊ CANADIAN JOURNAL OF PHILOSOPHY SUPPLEMENTARY VOLUME 13, 1987}

\section{SCIENCE, MORALITY AND FEMINIST THEORY}

EDITORS:

Marsha Hanen and Kai Nielsen

Marsha Hanen

Alison M. Jaggar

Annette C. Baier

Alison Wylie

Sandra Harding

Marilyn Friedman

Introduction: Toward Integration

Sex Inequality and Bias in Sex Differences Research

The Need for More Than Justice

Virginia Held

Sibyl Schwarzenbach

John Exdell

Kathryn Morgan

Steven Burns

Barbara Houston

Susan Sherwin

Christine Overall

Sheila Mullett

Ann Ferguson

The Philosophy of Ambivalence: Sandra Harding on The Science Question in Feminism
Ascetic Intellectual Opportunities: Reply to Alison Wylie

Beyond Caring: The De-Moralization of Gender

Non-Contractual Society

Rawls and Ownership: The Forgotten Category of Reproductive Labour

Ethics, Ideology, and Feminine Virtue

Women and Moral Madness

Moral Sanity or Who Killed Boy Staunton

Rescuing Womanly Virtues: Some Dangers of Moral Reclamation Feminist Ethics and In Vitro Fertilization

Surrogate Motherhood

Only Connect: The Place of Self-Knowledge in Ethics

A Feminist Aspect Therapy of the Self

Second Persons

Kai Nielsen

Afterword: Feminist Theory - Some Twistings and Turnings

PRICE:

CDN $\$ 14.00$ (in Canada)

US $\$ 12.00$ (outside Canada)

Please add $\$ 1.50$ for postage and handling, and $50 \notin$ for every further copy.

ISSN 0229-7051
ORDER FROM:

THE UNIVERSITY OF CALGARY PRESS, LT 1013

THE UNIVERSITY OF CALGARY

2500 UNIVERSITY DRIVE N.W.,

CALGARY, ALBERTA T2N IN4 CANADA 


\section{Philosophy OPublic Affairs}

"PHILOSOPHY AND PUBLIC AFFAIRS" was created to promote the discussion of matters of public concern, and to bridge the gap that exists between philosophers and those in other disciplines who are working on questions that raise philosophical issues. The journal has maintained a high level of discussion from the start." - Peter Singer, The New York Times Magazine

Articles from recent issues include:

- Legal Theory and the Claim of Authority By Philip Soper

- Killing, Letting Dle, and Simple Conflicts By Heidi Malm

- The Separation of Church and State and the Obligations of Clizenship by Robert Audi

- Justice, Health Care, and the Elderly by Dan W. Brock

- Three Grades of Social Involvement by George Sher

- Socrates and Athenian Democracy by T. H. Irwin Enter your Subscription Now.

Philosophy SPPublic G)Affairs
Foreign and domestic subscription rates: Individuals. \$18.00/yr. Insttiutions, \$31.50/yr. Forelgn postage and handling rate: \$7.00 PER YEAR.

\section{Subscriptions}

The Johns Hopkins University Press - Journals Publishing Division 701 W. 40th St., Suite 275 • Baltimore, Md. 21211-2190

Name

Address 


\section{An Interdisciplinary Journal of Philosophy}

EDITOR: ALASTAIR HANNAY

\section{Selected Articles from Vol. 32, 1989:}

Grant Gillett: Representation and Cognitive Science (No. 3)

Alison M. Jaggar: Love and Knowledge: Emotion in Feminist Epistemology (No. 2)

Jaegwon Kim: Honderich on Mental Events and Psychoneural Laws (No. 1)

Yuval Lurie: Wittgenstein on Culture and Civilization (No. 4)

Cbarles W. Mills: Is It Immaterial That There's a 'Material' in 'Historical Materialism'? (No. 3)

Antbony O'Hear: Evolution, Knowledge, and Self-consciousness (No. 2)

Jobn M. Preston: Folk Psychology as Theory or Practice? The Case for Eliminative Materi-

alism (No. 3)

Richard Schacht: Whither Determinism? On Humean Beings, Human Beings, and Originators (No. 1)

Harvey Siegel: Farewell to Feyerabend (Paul Feyerabend: Farewell to Reason) (No. 3)

Galen Strawson: Consciousness, Free Will, and the Unimportance of Determinism (No. 1)

INQUIRY is published quarterly by

\section{UNIVERSITETSFORLAGET}

(Norwegian University Press).

Subscription to be ordered from: Universitetsforlaget (Norwegian University Press),

P.O. Box 2959 Tøyen, 0608 Oslo 6, Norway, or U.S. Office: Publications Expediting Inc., 200 Meacbam Ave, Elmont, NY 11003, USA.

Please enter my subscription to INQUIRY

( 4 issues per year)

Rates 1989 (postage included - airmailed

to subscribers in the Americas):

Nordic countries only:

$\square \quad$ Institutions NOK 480,-

Individuals NOK 250,-

All other countries:

$\square$ Institutions USD 87,-

Individuals USD 45,-

NAME:

ADDRESS:

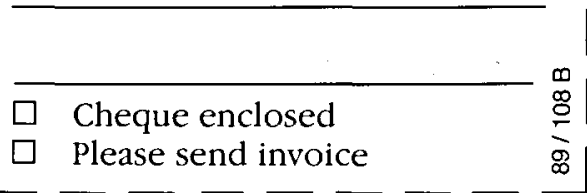




\section{the review of}

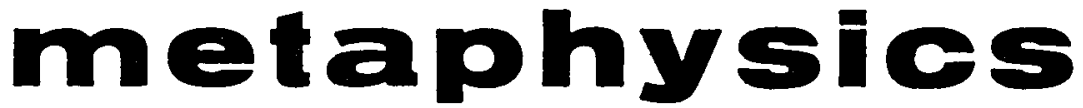

a philosophical quarterly

ISSN 0034-6632

\begin{tabular}{l|l|l|l|} 
SEPTEMBER 1989 & ） VOL. XLIII, No. 1 | ISSUE No. $169 \mid \$ 9.00$
\end{tabular}

articles

discussion

books received

philosophical abstracts

doctoral dissertations

visiting philosophers

retiring philosophers

announcements

ROBERT C. NEVILLE

NICHOLAS LOBKOWICZ

BEATRIZ BOSSI DE KIRCHNER

QUASSIM CASSAM

T. K. SEUNG

ERROL HARRIS

MARK M. HURLEY AND STAFF
Value, Courage, and Leadership

Substance and Reflection:

Aristotle and Hegel 


\section{THE CLASSICAL WORLD}

Since 1907 THE CLASSICAL WORLD has provided a combination of services and features which make the journal an indispensable instrument for teaching and research in the Classics. It is published six times yearly - from September to July.

\section{Articles}

Volume 83, in addition to its regular features such as Scholia and Paedagogus, will carry the following articles of scholarly and general interest:

"Teaching Classical Languages: A Reasonable Approach," "The Role of Comic Perspectives in Shaping Homer's Tragic Vision," "Catullus 14B," "Ovid, From Image to Narrative: Amores 1.8 and 3.6," "Love as Death: The Pivoting Metaphor in Vergil's Story of Dido," and "A Non-Classicist's View of the Volcanic Origins of the Polyphemus Study in the Odyssey."

$\boldsymbol{C W}$ will offer as well a survey of the currently available annotated Greek and Latin texts, and a supplementary survey of audiovisual materials in the Classics.

\section{Reviews}

THE CLASSICAL WORLD specializes in brief and expert reviews of new books in all areas of classical antiquity. Volume 83 will feature approximately 120 such reviews.

\section{Books Received}

The journal offers extensive and immediate listings of all books received from publishers around the world with complete bibliographical information.

For subscription information, write:

THE CLASSICAL WORLD

Department of Classics

Duquesne University

Pittsburgh, PA 15282 


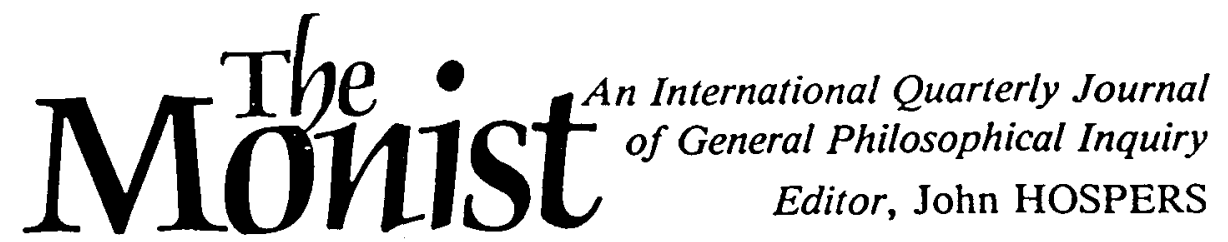

Edirorial Board: Henry E. Allison, John M. Cooper, Dagfinn Follesdal, R. Barcan Marcus, Joseph Margolis. Wallace I. Matson, Joseph Owens, Wilfrid Sellars, Anita Silvers, John E. Smith, Bruce Vermazen, Richard Wasserstrom.

Managing Editor: Sherwood J. B. SUGDEN

EACH ISSUE IS LIMITED TO ARTICLES ON A SINGLE GENERAL TOPIC. Communicate in advance with the Editor for special instructions. Two nonreturnable copies (one copy outside the U.S. and Canada) should be submitted NINE MONTHS PRIOR to the announced publiation date. Papers should be prepared for anonymous submission 10 readers, and should be from 10 to 20 double-spaced type written pages in length, including notes.

SCHEDULED PUBLICATION DATES:

$\begin{array}{llll}\text { Vol. 73, No. } 2 & \text { Apr., } 1990 & \text { The Theory of Interpretation } \\ \text { Vol. 73, No. } 3 & \text { July, } 1990 & \text { Systematic Pluralism } \\ \text { Vol. 73, No. } 4 & \text { Oct., } 1990 & \text { Property Rights } \\ \text { Vol. 74, No. } 1 & \text { Jan., } & 1991 & \text { Morality and the Self } \\ \text { Vol. 74, No. } 2 & \text { Apr., } & 1991 & \text { The Ontology of History } \\ \text { Vol. 74, No. } 3 & \text { July, } 1991 & \text { Hegel Today } \\ \text { Vol. 74, No. } 4 & \text { Oct., } 1991 & \text { Heracleitus } \\ \text { Vol. 75, No. } 1 & \text { Jan., } & 1992 & \text { Teleology \& the Foundation of Value } \\ \text { Vol. 75, No. } 2 & \text { Apr., } 1992 & \text { The Intrinsic Value of Nature } \\ \text { Vol. 75, No. } 3 & \text { July, } 1992 & \text { Christian Philosophy } \\ \text { Vol. 75, No. } 4 & \text { Oct., } 1992 & \text { Pragmatism: A Second Look } \\ \text { Vol. 76, No. } 1 & \text { Jan., } 1993 & \text { Person-Relativity in Ethics }\end{array}$

\section{Editorial Office: 8229 Lookout Mountain Ave., Los Angeles, CA 90046}

Business Office: Box 600, La Salle, Illinois 61301

SUBSCRIPTION RATES: United States: Annual (4 issues): Institutions, 528.00; Individuals, $\$ 18.00$.

2 years institutions, $\$ 50.00 ; 2$ years individuals, $\$ 32.00$.

Single copies: 57.00 . Foreign postage: Add 75 cents to single copy rate or $\$ 2.00$ per year of subscription. 


\section{GRAZER PHILOSOPHISCHE STUDIEN BAND 35 (1989)}

Inhalt: J. Haldane: Brentano's Problem. D. Münch: Brentano and Comte. J. Petrik: Two Facec Have "I". M. Holland: Emotion as a Basis of Belief. A. Ros: "Begriff", "Setzung", "Existenz" bei W.V.O. Quine. U. Meixner: Descartes' Argument für den psycho-physischen Dualismus im Lichte der modal-epistemischen Logik. A. Ward: The Relational Character of Belief. R.W. Trapp: Systematische Klassifikation und vergleichende Betrachtung der wichtigsten Ethiktypen.... Besprechungen. Buchnotiz.

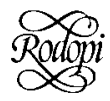

USA/Canada: Editions Rodopi, 233 Peachtree Street, N.E., Suite 404, Atlanta, Ga. 30303-1504, Telephone (404) 523-1964, only USA 1-800225-3998, Fax (404) - 522-7116

And Others: Editions Rodopi B.V., Keizersgracht 302-304, 1016 EX Amsterdam, Telephone (020) - 22.75.07, Fax (020) - 38.09.48

\section{ANTI-FOUNDATIONALISM AND PRACTICAL REASONING} CONVERSATIONS BETWEEN HERMENEUTICS AND ANALYSIS

\section{Edited with an Introduction by Evan Simpson}

\section{A volume of original essays}

The premise of the volume is the existence of common ground between different current methodologies in their rejection of foundationalism and emphasis on the practical. The four sections of the book are Practical Philosophy, Social-Political Critique, Moral Reflection, and Legal Deliberation.

$\begin{array}{lrr}\text { Clothbound } & \$ 35.95 & 0-920980-26-0 \\ \text { Paperbound } & \$ 17.95 & 0-920980-27-9\end{array}$

Order from: Academic Printing \& Publishing P.O. Box 4834

Edmonton, Alberta, Canada 
Acknowledgements/

Remerciements
The Canadian Journal of Philosophy is published with the aid of a grant from the Social Sciences and Humanities Research Council of Canada.

La publication du Canadian Journal of Philosophy est rendue possible grâce à un octroi du Conseil de Recherches $\mathrm{Hu}$ maines du Canada.

The Canadian Journal of Philosophy wishes to thank the University of Lethbridge for its generous support for the editorial administration of the journal.

The Canadian Journal of Philosophy tient à remercier l'Université de Lethbridge de l'aide généreuse qu'elle apporte à la gestion de sa rédaction.

The Canadian Journal of Philosophy is grateful for past support from its originating sponsor, the Canadian Association for Publishing in Philosophy. The Association is a non-profit organization, incorporated under the laws of Canada, with the object of promoting and publishing learned publications in philosophy. A regular member of the Association is a member of, and appointed by, any department of philosophy in a Canadian university, upon payment of a subscription by that department. The Association is a Registered Canadian Charitable Organization within the meaning of the Income Tax Act; donations to the Association are thus tax deductible.

The Canadian Journal of Philosophy désire exprimer sa gratitude à l'Association Canadienne des Publications en Philosophie qui l'a aidé par le passé. L'Association est un organisme à but non lucratif, incorporé aux termes de la loi canadienne, ayant pour objet la promotion et la publication d'études savantes en philosophie. Tout membre appartenant à, et désigné par, un département de philosophie d'une université canadienne est de facto, au reçu du règlement de l'abonnement départemental, membre à part entière de l'Association. L'Association est inscrite au Registre officiel des Organismes de Charité canadiens aux termes de la loi de l'impôt sur le revenu; les donations dont elle fait l'objet peuvent bénéficier ainsi du dégrèvement d'impôt. 